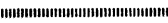 技術報告

\author{
森 田 喜 保*. 時 政 勝 行*2

\section{Prediction of Remaining Life of the Steel Shell of a Blast Furnace} \\ Yoshiyasu MORITA and Katsuyuki TOKIMASA
}

\begin{abstract}
Synopsis :
Thermal fatigue life evaluation is conducted for the steel shell of a blast furnace where hot spots have occurred repeatedly. Thermal elasto-plastic FEM analysis is used and, as a method of thermal fatigue life evaluation, the strain-range partitioning creep-fatigue analysis is adopted.

It is proved to be possible to predict the remaining life of the steel shell successfully based on the following results :

(1) It is the center of a hot spot on the inner surface of the steel shell that undergoes the largest cyclic deformation during a cycle of a hot spot.

(2) Thermal fatigue damages, which are accumulated by repetition of hot spots, consist of those resulted from both the plastic strain range and the ratchetting strain.

(3) A higher hot-spot temperature, a thicker steel shell and a larger hot-spot diameter reduce thermal fatigue life of the steel shell.

(4) Total value of thermal fatigue damages at the notched part of the steel shell can be detected by measuring the increase in shell thickness of its smooth part independent of a hot-spot temperature.
\end{abstract}

\section{1. 緒}

昭和 56 年 1 月〜 2 月に行われた住友金属工業(株)小 倉製鉄所第 2 高炉 (冷却盤高炉) の改修では，健全な鉄 皮を再使用する部分更新により経費の節減と工期の短縮 が図られたが，内表面の損傷状態が外部から把握できな い鉄皮の健全性をいかに評価し，いかなる基準で鉄皮を 更新するかが大きな課題であつた.

小倉第 2 高炉は火入れ後 1 年目からホットスポットが 発生し, 吹き止め時点までのホットスポット発生個所は 炉腹からシャフト下部の間の半周以上の範囲にわたり, 鉄皮表面まで貫通したクラックは4 個所, さらにUST (超音波探傷試験) で検知された炉内面クラックは 6 個 所を数えた.このようなホットスポットの繰返しによる クラックの発生は熱疲労損傷の蓄積によるものと判断さ れたが，クラック発生個所のホットスポット温度条件が 不明のため, クラックの発生するホットスポット回数を 正確に予測することが困難であつた．したがつて，鉄皮 更新基準の設定に際しては，鉄皮が過去の使用期間中に 経た温度履歴が不明確であるという事実を克服する必要 があつた。

そこで，筆者らは，まず簡単な高炉鉄皮ホットスポッ
トモデルを設定し，そのモデルの熱疲労寿命解析を行う ことにより，鉄皮の余寿命子測の可能性を検討した。そ の結果，鉄皮板厚の変化を求めれば，ホットスポット条 件のいかんにかかわらず，余寿命予測が可能であること が明らかとなつた。

本報はこのような熱疲労寿命余寿命解析結果とその実 高炉への適用結果をとりまとめたものである.

\section{2. 解 析 方 法}

高温材料の熱疲労寿命推定手法はこれまでに数多く提 案されているが，高炉ホットスポットのようにホットス ポット温度が材料のクリープ温度域まで上昇する場合に は, MANSON らの提案したひずみ範用分割法 (Strainrange partitioning creep-fatigue analysis, 略して SRP 法) が最も信頼性があると考えられる1) 3)。この 手法の特徵は, 熱疲学問題を変形解析問題と破壊抵抗性 の評価問題に分けて取り扱ら点であり，MANSONらは， この手法により，材料の破壊抵抗性が温度に鈍感な材料 固有の性質であり，従来より報告されている高温熱疲労 寿命の温度依存性は，材料に生じる非弾性ひずみが温度 条件に敏感なために生じる現象であることを明らかにし た.したがつて, 材料固有の破壊抵抗性をある一つの温

昭和 59 年 10 月本会講演大会にて発表 昭和 60 年 4 月 15 日受付 (Received A pr. 15, 1985)

* 住友金属工業(株)中央技術研究所工博 (Central Research Laboratories, Sumitomo Metal Industries, Ltd.)

*2 住友金属工業(株) 中央技術研究所 (Central Research Laboratories, Sumitomo Metal Industries, Ltd., 1-3 Nishinagasu-hondori Amagasaki 660) 
度で求めておけば, 熱疲労問題は変形解析問題に帰着す ることになる。

SRP 法による熱疲労寿命解析を厳密に逐行するため にはホットスポット繰返し時の詳細な非定常温度解析と その結果にもとづく非弾性解析を行ら必要があるが，こ こでは熱弾塑性解析を基本とした簡便法を採用し, 非弾 性ひずみすなわちクリープひずみの効果は解析に用いる 材料パラメータや寿命推定に用いる破壊抵抗性に含ませ ることにした。

\section{1 ホットスポット部の熱弾塑性解析}

Fig. 1 に示す円形のホットスポットモデルを考え, 外表面中心の温度が $20^{\circ} \mathrm{C}_{\rightleftarrows} \rightarrow T_{m a x}$ と変化する熱サイクル 条件下の応力・ひずみ挙動を熱弾塑性有限要素法により 求めた. Fig. 1（a）は鉄皮平滑部に, Fig. 1（b ）は 鉄皮応力集中部（実炬のコーミング孔部に相当. 円状開

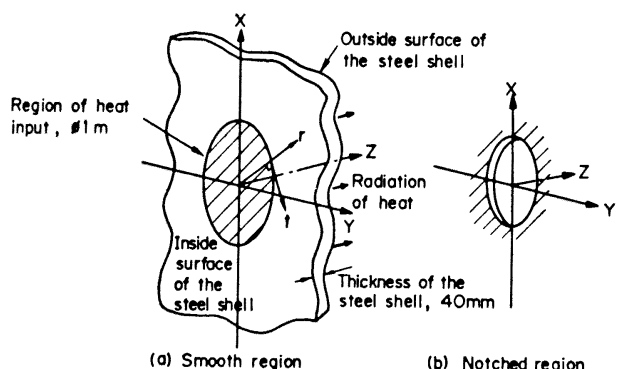

Fig. 1. Hot spot model for life prediction.

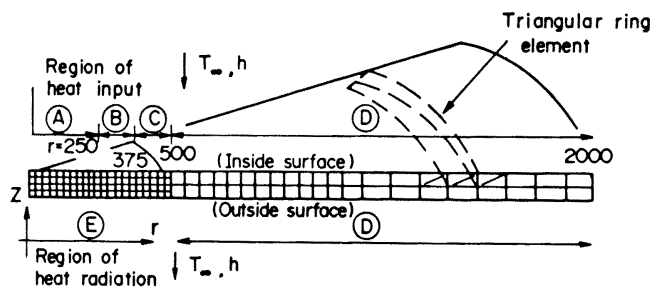

Fig. 2. Finite element model for thermal elastoplastic analysis. Different values of $h$ and $T_{\infty}$ are given at portions (A) (E) as shown in Table 1 .
口を仮定）にそれぞれホットスポット中心がある場合を 想定している．使用した熱荷重条件および材料物性值を Table 1, Table 2, Fig. 2 および Fig. 3 に示す. 実 炉鉄皮には炬内圧や内容物荷重が作用するが，局部的な 加熱による鉄皮熱応力と比較して応力の絶対值が十分小 さく，ここでは熱応力だけを検討の対象とした．実際に はホットスポット部の鉄皮外面を圧縮空気で冷却し，ま た炉内側にはモルタルを注入することが多く，代表的な 熱的条件として Table 1 に示す值を用いた。

Fig. 4 はホットスポット外表面中心温度 $T_{m a x}=700$ ${ }^{\circ} \mathrm{C}$ の場合の温度経時変化解析結果を示す. Fig. 5 に 示す実炉の温度パターンとの比較から, 今回採用した解 析条件は実炉の温度条件とほぼ一致していると言える。

ただし，内面の温度变化状態については実測データがな く, Fig. 4 の計算結果は内面の温度変化状況に関して は若干の不確かさを有していると考兄られる.

Fig. 6〜Fig. 9 は Fig. 4 の温度変化に対応する昇温 時および冷却時の応力とひずみの分布を示す。また，

Table 1. Heating and cooling conditions $\left(T_{\max }=\right.$ $700^{\circ} \mathrm{C}$ ). Portions (A) (E) are depicted in Fig. 3 .

\begin{tabular}{c|c|c|c|c|c|c}
\hline \multirow{2}{*}{} & \multicolumn{3}{|c|}{ Heating } & \multicolumn{2}{c}{ Cooling } \\
\cline { 2 - 7 } $\begin{array}{l}\text { Heat } \\
\text { transfer } \\
\text { coefficient }\end{array}$ & \multicolumn{2}{|c|}{$\begin{array}{c}\text { Temperature } \\
T_{\infty}\left({ }^{\circ} \mathrm{C}\right)\end{array}$} & $\begin{array}{l}\text { Heat } \\
\text { transfer } \\
\text { coefficient }\end{array}$ & $\begin{array}{l}\text { Temper } \\
\text { ature }\end{array}$ \\
\cline { 2 - 7 } & $\begin{array}{c}h\left(\mathrm{kcal} / \mathrm{m}^{2}\right. \\
\left.\mathrm{h}^{\circ} \mathrm{C}\right)\end{array}$ & $\begin{array}{l}0 \sim 5 \\
\mathrm{~min}\end{array}$ & $\begin{array}{l}5 \sim 10 \\
\mathrm{~min}\end{array}$ & $\begin{array}{l}10 \sim 40 \\
\mathrm{~min}\end{array}$ & $\begin{array}{c}h\left(\mathrm{kcal} / \mathrm{m}^{2}\right. \\
\left.\mathrm{h}^{\circ} \mathrm{C}\right)\end{array}$ & $T_{\infty}\left({ }^{\circ} \mathrm{C}\right)$ \\
\hline (A) & 500 & & & & 20 & \\
(B) & 300 & 600 & 700 & 800 & 20 & 20 \\
(D) & 100 & 20 & 20 & 20 & 20 & 20 \\
(D) & 20 & 20 & 20 & 20 & 100 & 20 \\
\hline (E) & 100 & 20 & 20 & & \\
\hline
\end{tabular}

Table 2. Physical properties of shell used in the calculation.

\begin{tabular}{lc|c}
\hline Thermal conductivity & $\left(\mathrm{kcal} / \mathrm{mh}^{\circ} \mathrm{C}\right)$ & 46 \\
\hline Specific heat & $\left(\mathrm{kcal} / \mathrm{kg}^{\circ} \mathrm{C}\right)$ & 0.11 \\
\hline Specific gravity & $\left.\mathrm{kg} / \mathrm{m}^{3}\right)$ & 7800 \\
\hline Linear expansion coefficient & & $0.135 \times 10^{-4}$ \\
\hline Poisson's ratio & 0.3 \\
\hline
\end{tabular}

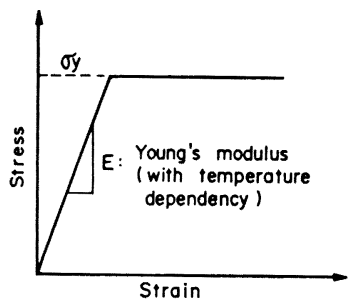

(a) Stress-strain relationship

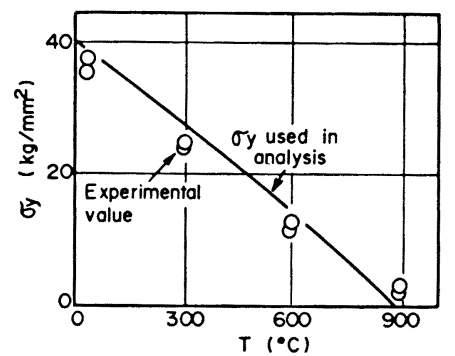

(b) Temperafure dependence of $\sigma_{y}$
Fig. 3. Yielding properties of the blast furnace shell material, SM50CN. 


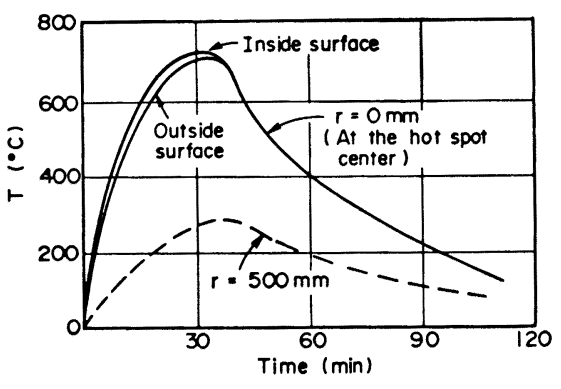

Fig. 4. An example of the analysis of variation of the hot spot temperature with time.
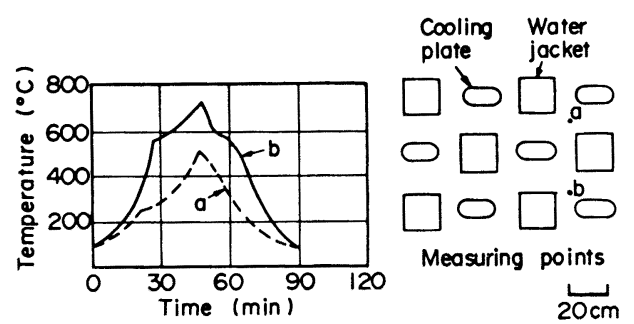

Fig. 5. Variation of the hot spot temperature with time, measured on the blast furnace.

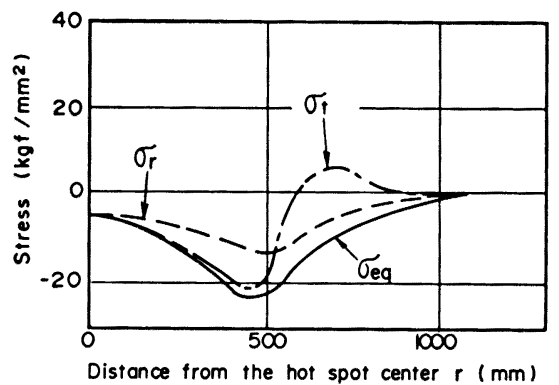

Fig. 6. Thermal stress distribution around a hot spot when the maximum temperature rise is reached (Inside surface).

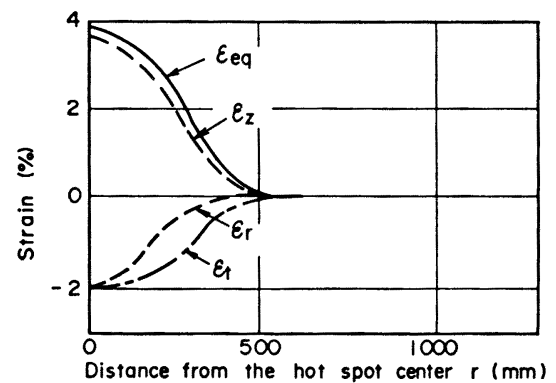

Fig. 7. Thermal strain distribution around a hot spot when the maximum temperature rise is reached (Inside surface).

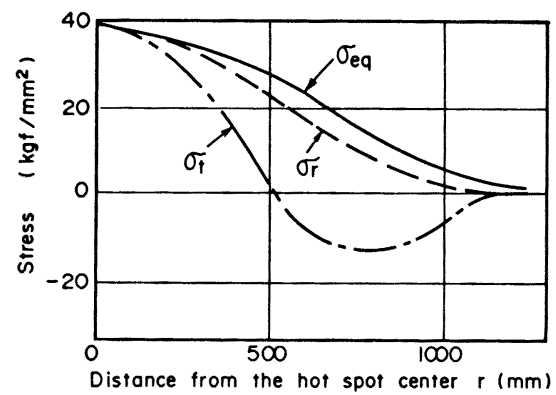

Fig. 8. Residual stress distribution around a hot spot after cooled (Inside surface).

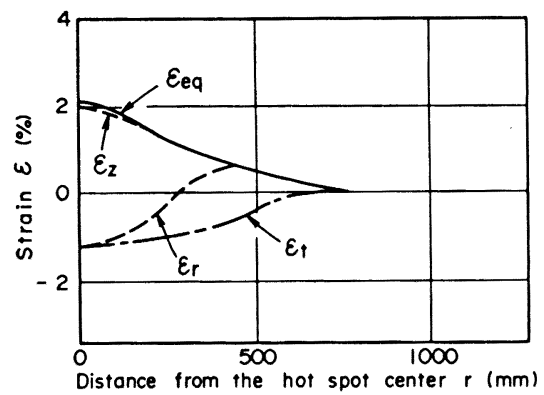

Fig. 9. Residual strain distribution around a hot spot after cooled (Inside surface).

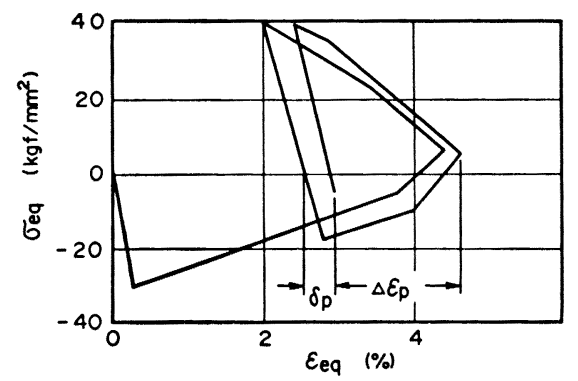

Fig. 10. Effective stress versus effective strain relationship at the hot-spot center on the inside surface during cyclic occurrence of hot spots $\left(T_{\max }=700^{\circ} \mathrm{C}\right)$.

Fig. 10 はホットスポット中央部での相当応力 $\sigma_{e q}$ と相 当ひずみ $\varepsilon_{e q}$ の関係を示す.ここで， $\sigma_{e q}, \varepsilon_{e q}$ は次式で 表示される量であり，多軸状態にある個所の降伏挙動あ るいは変形挙動を単軸状態と対比して記述する場合に使 用されている一般的なパラメーターである.

$$
\begin{aligned}
& \sigma_{e q}=\frac{1}{\sqrt{2}} \sqrt{\left(\sigma_{r}-\sigma_{t}\right)^{2}+\left(\sigma_{t}-\sigma_{z}\right)^{2}+\left(\sigma_{z}-\sigma_{r}\right)^{2}} \\
& \varepsilon_{e q}=\frac{\sqrt{2}}{3} \sqrt{\left(\varepsilon_{r}-\varepsilon_{t}\right)^{2}+\left(\varepsilon_{t}-\varepsilon_{z}\right)^{2}+\left(\varepsilon_{z}-\varepsilon_{r}\right)^{2}}
\end{aligned}
$$




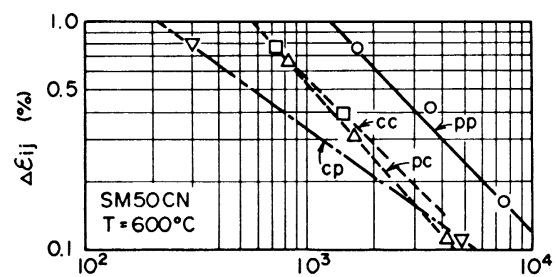

$\mathrm{Nij}_{\mathrm{ij}}$ (cycles)

Fig. 11. $\Delta \varepsilon_{i j}-N_{i j}$ relationships obtained for SM50CN.

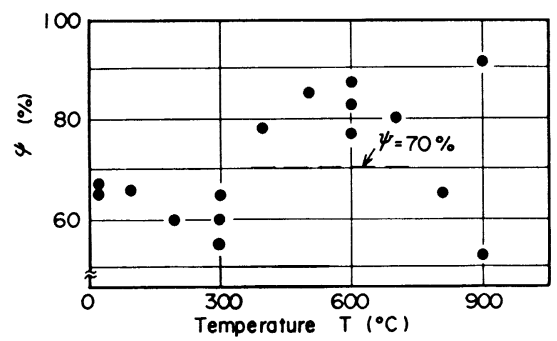

Fig. 12. Temperature dependence of $\psi$.

Fig. 10 において $\sigma_{e q}$ と $\varepsilon_{e q}$ の関係を図示する場合に は，それぞれの符号を絶対值が最大となる応力とひずみ の符号に合わせた。

Fig. 6〜Fig. 10 より以下のことが明らかとなつた。

（1）最も大きなひずみ履歴を受け熱疲労強度が問題 となるのはホットスポット中心炉内側である.

（2）ホットスポット中心部の残留応力はほほ鉄皮材 の降伏応力に等しい.

（3）板厚はホットスポットの繰返しとともに増加す る。

（4）相当応力と相当ひずみの関係（ヒステリシスル ープ）は閉じず，繰返しひずみ状態は塑性ひずみ範囲 $\Delta \varepsilon_{p}$ とラチェットひずみ $\delta_{p}$ の二つの変数で記述でき る.ラチェット変形は 1 サイクル目がとくに大きく， 2 サイクル目以降は $\delta_{p}$ に等しい. (Fig. 10)

\section{2 熱疲労寿命推定式}

上述の解析の結果, ホットスポット発生部では, ホッ トスポット中央部でのホットスポットの発生に伴う高温 圧縮塑性変形と温度低下時の引張りの塑性変形といら単 なる塑性変形の繰返し $\left(\Delta \varepsilon_{p}\right)$ だけでなく， 1 サイクル ごとに一方向の変形が蓄積 $\left(\delta_{p}\right)$ することが明らかとな り, $\delta_{p}$ を寿命推定時に考慮に入れる 必要があることが わかつた.

そこで, MANSON and HALFORD4) に従い, 次式をホ ットスポット部のクラック発生寿命 $N_{f}$ の推定式とし
て用いた。

$$
\frac{1}{N_{p}}+\frac{\delta_{p}}{D_{p}}=\frac{1}{N_{f}}
$$

ただし， $N_{p}$ は $\Delta \varepsilon_{p}$ に対応する寿命， $D_{p}$ は引張破断延 性であり， $\Delta \varepsilon_{p}-N_{p}$ 関係， $D_{p}$ はそれぞれ繰返し変形， 一方向変形に対する材料の破壊抵抗性である.

\section{3 鉄皮材の $\Delta \varepsilon_{p}-N_{p}$ 関係および $D_{p}$ 值}

温度 $600^{\circ} \mathrm{C}$ において 4 種類の試験 (PP, PC, CP お よび CC 試験）を実施し，実験結果を SRP 法で解析す ることによつて定めた鉄皮材 SM50CN の $\Delta \varepsilon_{p p}-N_{p p}$, $\Delta \varepsilon_{p c}-N_{p c}, \Delta \varepsilon_{c p}-N_{c p}$ および $\Delta \varepsilon_{c c}-N_{c c}$ 関係を Fig. 11 に示す5). Fig. 11 から明らかなように，ひずみの大き い領域 $(>0.2 \%)$ では, $\Delta \varepsilon_{c p}-N_{c p}$ 関係が下限寿命を与 える. 本研究では, $2 \cdot 1$ で行つた弾塑性解析がクリープ 温度域の変形を求めていることを考虑し， $\Delta \varepsilon_{c p}-N_{c p}$ 関 係を式 ( 3 )の寿命推定に用いる $\Delta \varepsilon_{p}-N_{p}$ 関係として採用 した.

$$
\Delta \varepsilon_{p}=49.6 N_{p}^{-0.721}
$$

$D_{p}$ 值については Fig. 12 に示す引張破断絞り $\psi$ の温 度依存性データより，T=500 750 ${ }^{\circ} \mathrm{C}$ の温度域での下 限值として $\psi=70 \%$ ，すなわち $D_{p}=120 \%$ を用いた。 実際に生じるラチェット変形にはクリープ変形も含まれ ており，一方向変形に対する破壊抵抗性としてはクリ一 ブ破断延性も考慮する必要があるが，データの収集に時 間がかかることやJIS にもとづく高温引張試験速度がか なり遅く, $600^{\circ} \mathrm{C}$ 以上の温度では $D_{p}$ 值にもクリープの 影響が反映されていると判断し，クリープ破断延性は用 いなかつた。

\section{3. 解 析 結 果}

\section{$3 \cdot 1$ 平滑部および応力集中部の $\Delta \varepsilon_{p} ， \delta_{p}$ に及ぼすホ ットスポット条件の影響}

ホットスポット条件として， $T_{\text {max }}$, 鉄皮板厚, ホッ トスポット直径を選び，それぞれの $\Delta \varepsilon_{p} ， \delta_{p}$ に及ぼす 影響を解析した。

Fig. 13 および Fig. 14 は平滑部と応力集中部それ ぞれについて $\Delta \varepsilon_{p}$ および $\delta_{p}$ に及ぼすホットスポット 温度 $T_{\text {max }}$ の影響を図示したものである。これから， $T_{\text {max }}$ が大となるほど $\Delta \varepsilon_{p}$ および $\delta_{p}$ が直線的に増大 することがわかる． また，応力集中部の $\Delta \varepsilon_{p}, \delta_{p}$ は平 滑部と比較し，それぞれ 1.8 倍, 2.0 倍である.

Fig. 15 は鉄皮板厚を変化させた時の $\Delta \varepsilon_{p}, \delta_{p}$ を求 めたものである．板厚が増大すると $\Delta \varepsilon_{p}, \delta_{p}$ が増大す ることがわかる.

Fig. 16 はホットスポット直径 $D$ を変化させた場合 


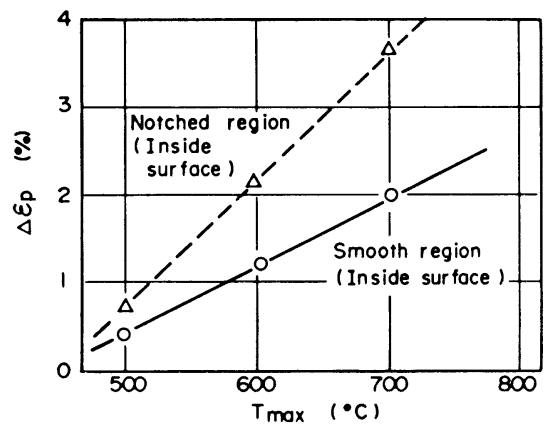

Fig. 13. Effect of $T_{m a x}$ on $\Delta \varepsilon_{p}$ (Shell thickness $40 \mathrm{~mm}$, hot spot diameter $1 \mathrm{~m}$ ).

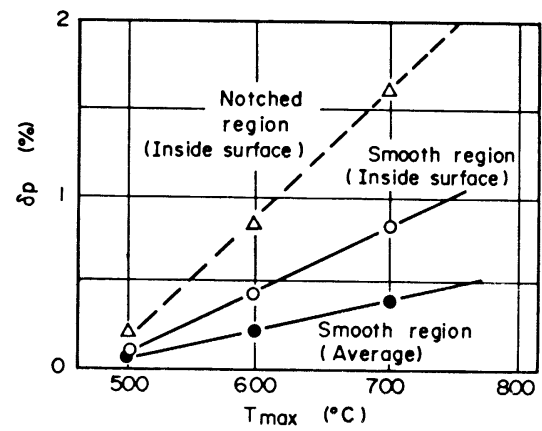

Fig. 14. Effect of $T_{m a x}$ on $\delta_{p}$.

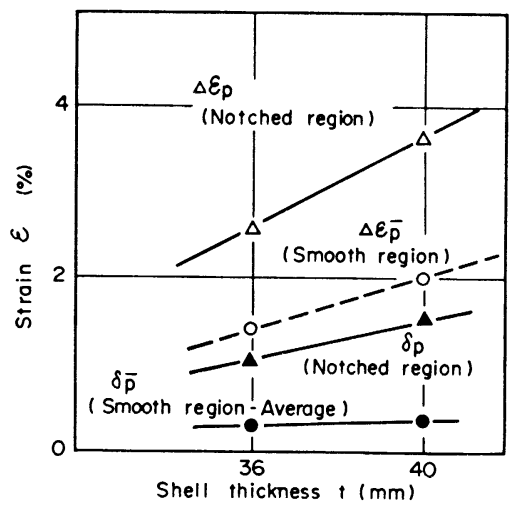

Fig. 15. Effect of shell thickness on $\Delta \varepsilon_{p}$ and $\delta_{p}$. の結果であり，直径が増大すると $\Delta \varepsilon_{p}, \quad \delta_{p}$ は増大する が，板厚やホットスポット温度の影響に比べるとその影

響は小さいことがわかる。

\section{2 許容ホットスポット発生回数}

Fig. 17 は応力集中部の炉内側表面がある一定の損傷 に達するホットスポットの許容発生回数とホットスポッ ト中心温度 $T_{\max }$ との関係を板厚 $40 \mathrm{~mm}$, ホットスポ ット直径 $1 \mathrm{~m}$ の場合について示したものである．損傷 度 $\alpha$ は $N / N_{f}$ で表示されている.これから， $T_{\text {max }}$ が

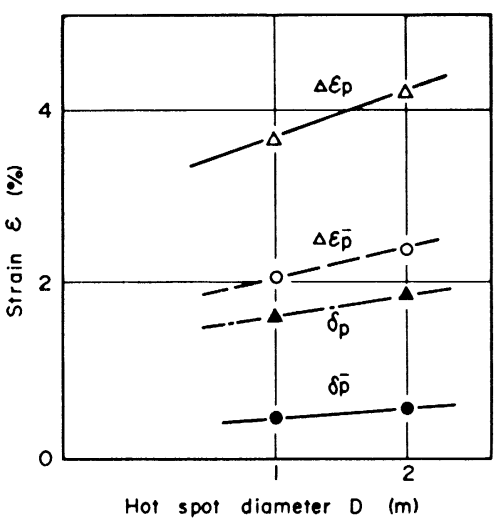

Fig. 16. Effect of hot spot diameter on $\Delta \varepsilon_{p}$ and $\delta_{p}$.

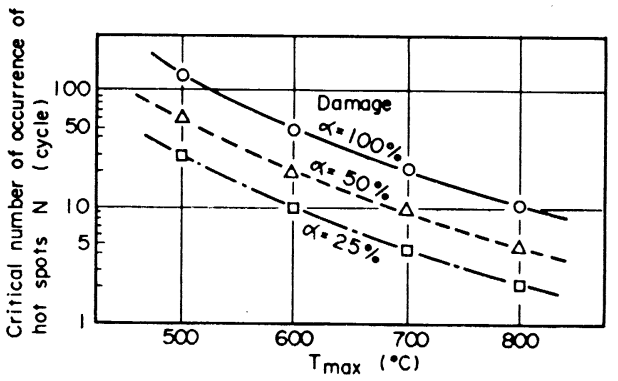

Fig. 17. Effect of $T_{m a x}$ on the critical number of occurrence of hot spots for the steel shell failure $(t=40 \mathrm{~mm}, D=1 \mathrm{~m}) \quad\left(\alpha=N / N_{f}\right)$.

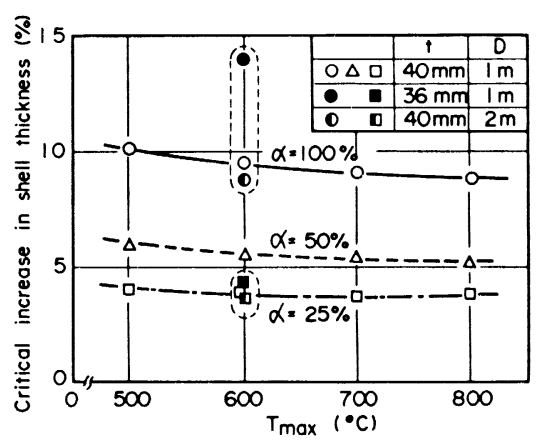

Fig. 18. Effect of $T_{m a x}$ on the critical increase in shell thickness of smooth region for the steel shell failure $\left(\alpha=N / N_{f}\right)$.

大となるほど寿命は短くなることがわかる。

\section{$3 \cdot 3$ 許容板厚增大率}

$2 \cdot 2$ で示したよらにホットスポット部の板厚はホット スポットの繰返しに伴い増大し， $T_{\text {max }}$ が大となるほど その傾向は著しい。一方，ホットスポット部の寿命は $T_{\text {max }}$ が大となるほど低下する.そこで，ホットスポッ ト部が一定の損傷度に達する許容板厚増大率はホットス 
ポット温度に対して鈍感となるのではないかと考え，許 容板厚増大率之 $T_{\max }$ の関係を損傷度 $\alpha$ をパラメータ 一として求めた.

Fig. 18 は, 応力集中部の炉内側表面がある一定の損 傷度に達したときの平滑部の板厚増大率（許容板厚増大 率) と $T_{\text {max }}$ の関係を示す。 これから次のことが明ら かである。

(1) 許容板厚増大率はホットスポット外径 $D$ と $T_{\text {max }}$ が変化してもあまり変化しない。

（2）許容板厚増大率は板厚によつて大きく異なり, 板厚が大きくなるほど小さくなる傾向にある。

\section{4. 実炬への適用}

ホットスポットが発生した鉄皮の余寿命を操業条件と の関連で評価する場合，Fig. 18 によれば，ホットスポ ット条件 $\left(T_{\max }\right.$ や $\left.D\right)$ が不明でも, ホットスポット 条件が寿命の全期間にわたつて変動しないと仮定する と，実炉鉄皮の板厚増大率がわかれば損傷度 $\alpha$ を知る ことができる。さらに，それまでのホットスポット発生 回数がわかれば余寿命（=N/ $\alpha-N)$ を知ることができ ることになる，実炉に扔いては $T_{\text {max }}$ の把握が困難で あることを考虑すると，Fig. 18 は実用上さわめて有用 な知見であると言える。

以下，小倉製鉄所第 2 高炉への適用結果について述べ る.

\section{1 小合第 2 高炉改修前における鉄皮板厚增大率と} ホットスポット発生回数

Fig. 19 は, 小倉 2 号高炉 (鉄皮板厚 $t=40 \mathrm{~mm}$ ) に 颃いてホットスポット発生部の板厚增大率とホットスポ ッ発生回数の関係を改修前に求めた結果である。図に おいて, 一印は貫通クラック発生部位を示し，実線は Fig. 18 の損傷度 $\alpha=100 \%$ となる板厚増大率であり, 一点鎖線は損傷度 $\alpha=25 \%$ となる板厚増大率を示す。

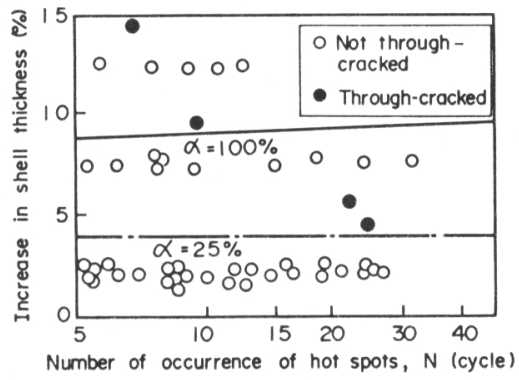

Fig. 19. Relationship between the increase in shell thickness and the number of occurrence of hot spots at through-cracked portions and not through-cracked ones, measured before the replacement.

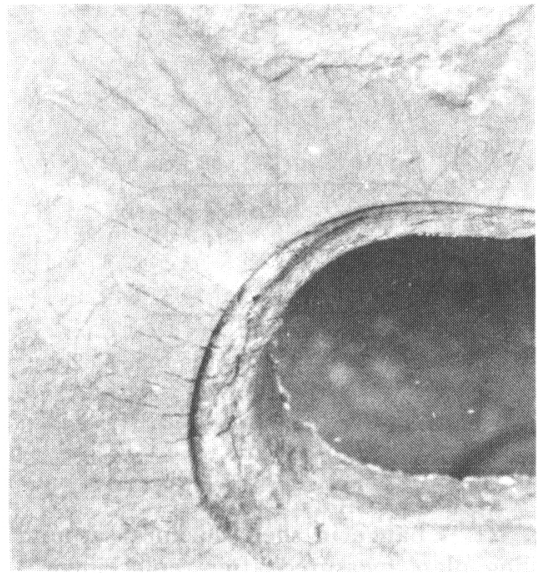

Photo. 1. An example of cracks found on the inner surface of the replaced steel shell.

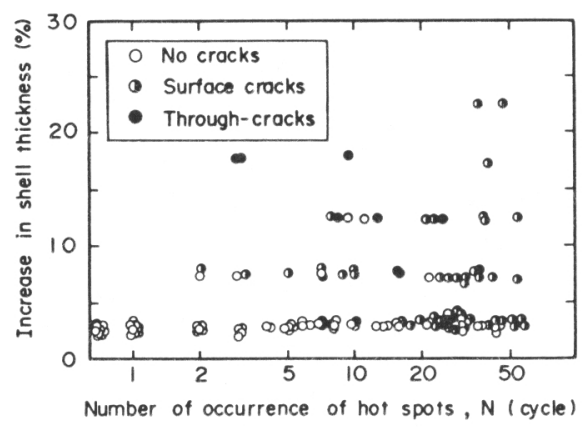

Fig. 20. Relationship between the increase in shell thickness and the number of occurrence of hot spots obtained based on the results of detailed examination of the inside surface of the replaced steel shell.

実炉で発見された貫通クラックは板厚増大率 $4 \%$ 以上 またはホットスポット発生回数 7 回以上の部位で生じて いる.

これから，本解析結果は，貫通クラックの数が少ない けれども，実炉データの平均傾向を予測しており，ホッ トスポット条件 $\left(T_{\max }, D\right)$ の明確でない小倉第 2 号 高炉ホットスポット部の更新の判断基準の一助となり得 ることがわかる。

4.2 小倉第 2 高炉改修部位の板厚增大率, ホットスポッ ト発生回数および内面クラック発生状況

Photo. 1 は鉄皮改修部位の内表面に認められたクラ ックの典型例を示す. クラックの大ささ，形状から次の よらな4 種類に分類できると判断された。

（1）コーミング応力集中部から放射線状に炉内面に 広がつたクラック (深さ数 $\mathrm{mm}$, 長さ数 $100 \mathrm{~mm}$ )

（2）コーミング間のクラック（深さ数 $\mathrm{mm}$ 程度） 


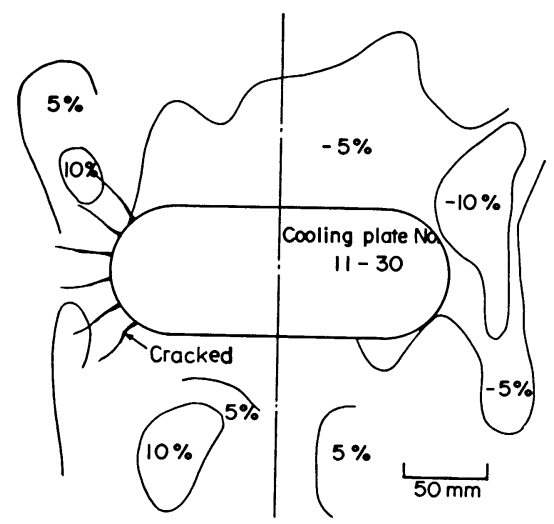

Fig. 21. Change in shell thickness around a cooling plate measured after replacement.

(3) コーミング間の亀甲状クラック

(4) 貫通クラック (6力所)

Fig. 20 は, 鉄皮内表面状態を上述 (1)〜 (3)の表面 クラック，(4)の貫通クラックおよび健全部に分類し て，各部位の板厚増大率とホットスポット発生回数の関 係をまとめたものである. また，Fig. 21 はコーミング 孔周辺の板厚変化の分布をUSTにより測定した結果を 示す. Fig. 21 から明らかなよらに, クラック発生部分 の板厚の増大率は小さくてもその近傍に $8 \%$ 以上の板 厚増大率を示す部分が存在することがわかる. Fig. 20 においてホットスポット発生回数が 0 でも板厚に变化が 認められるのは板厚測定個所から離れたところで発生 したホットスポットの影響を受けたものと考えられる。

Fig. 20 に示す結果はクラック発生場所の板厚増大率と ホットスポット回数の関係で示されているので，今回の 解析結果と対比するのは厳密には正しくない。さしろ, クラック発生部を中心とする円領域を考え，その領域で の最大板厚増大率と最多ホットスポット回数との関係で 示した方がよいと思われる.

Fig. 22 は半径 $R=1 \mathrm{~m}$ および $R=2 \mathrm{~m}$ の円領域を 考えたときの結果である. 簡単のため, 鉄皮板厚増大率 の領域を $0 \sim 5 \%, 5 \sim 10 \%, 10 \sim 15 \%, 15 \sim 20 \%$ およ び 20〜25\% に区分し，調査した全 59 個所のクラック 発生部位に対する結果が一つのデータ点としてプロット されている. この結果から, 変形領域から $2 \mathrm{~m}$ 以内に 内表面クラックの発生を想定するときはその変形領域の 許容板厚増大率は $10 \%$ であることがわかる.この結果 は, 本解析結果（許容板厚増大率 $8 \%$ ）との比較から, 実炉でのホットスポット直径として $4 \mathrm{~m}$ を選べば，本 解析結果がそのまま鉄皮更新基準として使用できること を示唆している.
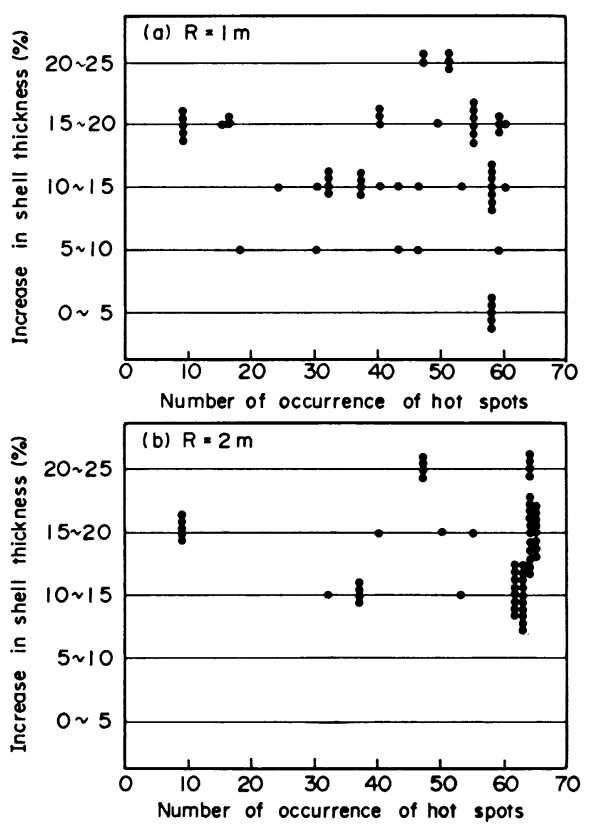

Fig. 22. Relationship between the maximum increase in shell thickness and the maximum number of occurrence of hot spots in circular regions of the radius $R$ of which centers are cracked portions.

\section{5. 結}

鉄鋼の基幹設備である高炉の鉄皮ホットスポット部の 余寿命予測問題に対し, 高温材料の高温クリープ疲労寿 命推定法として最近有望視されつつあるひずみ範囲分割 法の概念を適用し, 弾塑性解析を基本とした簡易寿命推 定を実施した。 その結果, 㛜密な取扱いに比べ本研究の 手法には改善すべき仮定がいくつか含まれているもの の，実際の高炉鉄皮の余寿命を実用上十分な精度で予測 し得ることがわかつた.

本研究で明らかとなつた事柄をまとめると次のとおり である・

（1）ホットスポット発生部で最も大きいひずみ履歴 を受け熱疲労が問題となるのはホットスポット中心炉内 側であり，ホットスポットの繰返しによる鉄皮の損傷は 塑性ひずみ範用 $\Delta \varepsilon_{p}$ とラチェットひずみ $\delta_{p}$ によるも のである.

(2) $\Delta \varepsilon_{p}$ と $\delta_{p}$ を考虑して，かつ $\Delta \varepsilon_{p}$ をすべて $\Delta \varepsilon_{c p}$ と仮定して求めた寿命は，ホットスポット温度が 高くなるほど，また板厚が大となるほど短くなる。ま た，ホットスポット直径も大となるほど短くなるが，そ の程度は温度や板厚の影響に比べて小さい。 
（3）鉄皮開口部のホットスポットの繰返しによる 損傷度が一定の值に達するときの平滑部の板 厚增大率 は，ホットスポット温度によらずほぼ一定となる。鉄皮 開口部炉内表面にクラックが発生する許容板厚增大率 は, 板厚の影離を受け，板厚 $40 \mathrm{~mm}$ のとき $8 \%$, 板厚 $36 \mathrm{~mm}$ のとさ $14 \%$ であり，末たホットスポット直径 が増大するとわずかではあるが減少する傾向にある.

（4）（3）で得られた知見を小倉製鉄所第 2 高灯の短 期部分改修に適用し，更新すべき部位を十分な精度で子 測できることを確認した。また，改修後の鉄皮内表面調 查結果から, 板厚 $40 \mathrm{~mm}$ の場合, 実炉ホットスポット 直径を $4 \mathrm{~m}$ と考えれば，（3）の知見をそのまま鉄皮更 新基準として使用できると判断された。

\section{記 号}

$D:$ ホットスポット直径 $(\mathrm{m})$

$D_{p}:-100 \ln (1-\varphi / 100): \delta_{p}$ の蓄積により破壊が生 ナ゙るときの限界ひずみ量（\%)

$E:$ : サグ率 $\left(\mathrm{kgf} / \mathrm{mm}^{2}\right)$

$h$ : 熱伝達倸数 $\left(\mathrm{kcal} / \mathrm{m}^{2} \mathrm{~h}^{\circ} \mathrm{C}\right)$

$N:$ ホットスボット発生回数（サイクル）

$N_{f}:$ ホットスボットによるクラック発生. 命 (サイクル)

$N_{p}: \Delta \varepsilon_{p}$ に対応する披労寿命（サイクル）

$N_{p p}, N_{p c}, N_{c p}, N_{c c}: d \varepsilon_{p p}, d \varepsilon_{p c}, d \varepsilon_{c p}, d \varepsilon_{c c}$ に対応す る疲労寿命（サイクル）

$R$ : クラック発生部を中心とする川領域の半径 (m)

$t$ : 鉄皮板厚 $(\mathrm{mm})$

$T:$ 鉄皮温度 $\left({ }^{\circ} \mathrm{C}\right)$

$T_{\text {max }}$ : ホットスポット中心外表面温度 $\left({ }^{\circ} \mathrm{C}\right)$

$T_{\infty}$ : 鉄皮周辺外気温度 $\left({ }^{\circ} \mathrm{C}\right)$

$\alpha: N / N_{f}:$ 損傷度

$\delta_{p}: 1$ サイクルに生ずる塑性ラチェット変形（\%) $\bar{\delta}_{p}: \delta_{p}$ の板厚方向平均值 $(\%)$

$\varepsilon_{e q}:$ 相当ひず文 $(\%)$

$\varepsilon_{r}, \varepsilon_{t}, \varepsilon_{z}$ : 半径方向, 円周方向，板厭方向ひず办 $(\%)$

$\Delta \varepsilon_{i j}-N_{i j}$ 関係 : $\Delta \varepsilon_{p p}-N_{p p}, d \varepsilon_{p c}-N_{p c}, d \varepsilon_{c p}-N_{c p}$, $\Delta \varepsilon_{c c}-N_{c c}$ 関係の略称

$\Delta \varepsilon_{p}:$ 塑性ひずみ範囲 $(\%)$

$d \bar{\varepsilon}_{p}: \Delta \varepsilon_{p}$ の板厚方向平均值 $(\%)$

$\Delta \varepsilon_{p p}$ : 引張り，压縮ともクリーブ变形を含まない塑性 変形からなる繰返し変形（\%)

$\Delta \varepsilon_{p c}$ : 引張側塑性変形, 压縮側クリーナ゙变形からなる 繰返乙変形 $(\%)$

$\Delta \varepsilon_{c p}$ : 引張側クリーブ変形, 压縮側塑性変形からなる 繰返し変形 $(\%)$

$\Delta \varepsilon_{c c}$ : 引張, 压縮ともクリープ変形からなる繰返し変 形 $(\%)$

$\sigma_{e q}:$ 相当応力 $\left(\mathrm{kgf} / \mathrm{mm}^{2}\right)$

$\sigma_{r}, \sigma_{t}, \sigma_{z}$ : 半径方向, 円周方向, 板厚方向灾力 $\left(\mathrm{kgf} / \mathrm{mm}^{2}\right)$

$\sigma_{y}$ : 降伏強度 $\left(\mathrm{kgf} / \mathrm{mm}^{2}\right)$

$\psi$ : 引張試験により得られる破断絞り

\section{交献}

1) S. S. Manson, G. R. Halford and $M . H$. Hirschberg: Design for Elevated Temperature Environment (1971), p. 12 [ASME]

2 ) S. S. Manson: Fatigue at Elevated Temperatures, ASTM STP 520 (1973), p. 744 [ASTM]

3 ) G. R. Halford and $S . S$. Manson: Thermal Fatigue of Materials and Components, ASTM STP 612 (1975), p. 239 [ASTM]

4) S. S. Manson and G. R. Halford: 1976 ASME-MPC Symposium on Creep-Fatigue Interaction, MPC-3 (1976), p. 299 [ASME]

5 ) $K$. Hirakawa and $K$. Tokimasa: The Sumitomo Search No. 26 (1981), p. 118 